\title{
Implementing a total reward strategy in selected South African municipal organisations
}

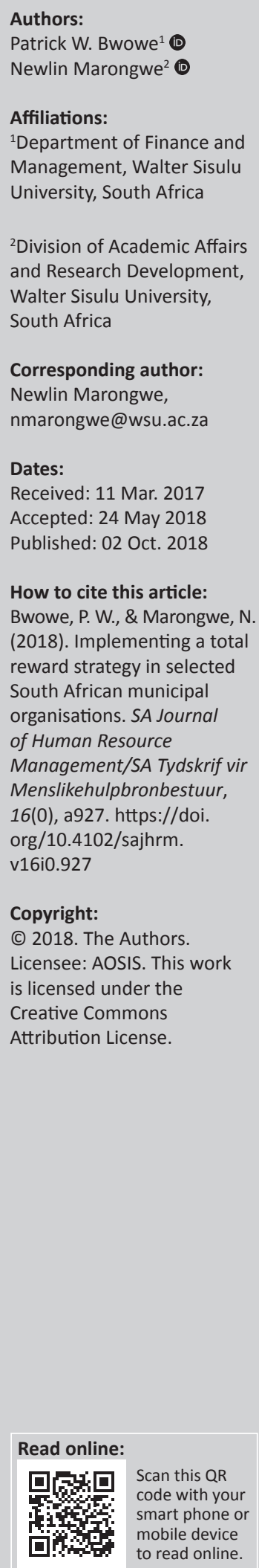

Orientation: The role of total rewards in achieving business goals, employee productivity and employee retention cannot be underestimated. A total reward strategy has been linked to the entire employee proposition making it a critical factor in the attraction and retention of talent in organisations.

Research purpose: The study focused on investigating the extent to which municipal organisations are implementing total rewards practices.

Motivation for the study: The study was motivated by the desire to explore the extent South African municipalities are implementing total rewards as a basis of their reward system and to find out which total reward practices are implemented by municipalities as part of their compensation and reward strategy.

Research approach/design and method: The study used an internet-based survey with a questionnaire to assess managers' perception of total reward strategy and the extent it is implemented in their organisations. A non-list-based random sampling technique was used to draw up a sample of 58 human resources managers from selected municipalities. Descriptive statistics was used to analyse the survey.

Main findings: The study found out that few of the responding municipalities had implemented the total reward strategy.

Practical/managerial implications: Municipalities should re-think their approach to compensation by ensuring that total rewards programmes are developed and implemented.

Contribution/value add: The findings contribute to new knowledge that can be used by municipal employers to attract the required talent capable of ensuring effective service delivery, through developing competitive reward strategies that can command high employee satisfaction, loyalty and commitment to the organisation.

\section{Introduction}

Reward management, as asserted by Armstrong, Brown and Reilly (2009), is concerned with the processes of developing, implementing, operating and evaluating reward policies and practices that recognise and value people according to the efforts and contributions they make towards achieving organisational, departmental and team goals. Organisations have put up reward systems consisting of the interrelated processes and practices of financial and non-financial rewards that combine into a total rewards approach to ensure that reward management is carried out to the benefit of the organisation and the people who work there (Armstrong \& Taylor, 2014, p. 359).

Armstrong (2006) and Jiang (2009) refer to rewards as the compensation employees receive from organisations for their services. A reward strategy describes what the organisations propose to give their employees as a reward for their performance. It constitutes a framework for developing and implementing reward policies, practices and processes. And as Armstrong and Taylor (2014) assert, it is intended to achieve three major objectives: performance, competitiveness and fairness. It also provides answers to two basic questions: (1) what do we need to do about our reward practices to ensure that they are fit for purpose? And (2) how do we intend to do it? The two authors further observe that a reward strategy is a declaration of intent that defines what the organisation wants to do in the future to develop and implement reward policies, practices and processes that will further the achievement of its business goals and meet the needs of its stakeholders. 


\section{Theoretical framework}

Reward strategies have their root in the content and process theory of motivation. The content theory of motivation focuses on factors that energise, direct, sustain and stop behaviour. Content theorists such as Maslow and Alderfer stressed the importance of need satisfaction in the motivation process, although there were some differences in their conceptualisation, categorisations of needs and their motivational levels (Alderfer, 1989; Maslow, 1943). On the other hand, the process theorists focussed on what drives, sustains and stops behaviour. Skinner and Belmont (1993), for instance, explained motivation to learn as consequences of teacher behaviour and student engagement while Adams (1965) contends that motivational programmes should be perceived as equitable and fair to all employees.

An important implication that can be derived from both the content and process theories of motivation is that decisions about rewards should be broad and holistic. They should take into account the fact that people have different needs at different times, and as such, flexible reward systems, which do not rely too heavily on financial rewards, should be developed. Rewards should not only be performance orientated but also be seen by employees as being fair and developmentally orientated. Reward programmes should enable employees to set goals to direct behaviour, ensure voluntary choices about how performance will occur and how it can be accomplished and what outcomes will employees choose as desirable.

The study is also rooted in the National Public Management (NPM) theory. The theory is a discrete set of ideas that can be broadly divided into two categories: firstly, where it advocates for the use of private management ideas, such as the provision of more responsive and efficient services, performance agreements including service standards, greater autonomy and flexibility for managers, new financial techniques; and secondly, the greater use of market mechanisms, such as privatisation and public-private partnerships in service provision (Cameron, 2009, p. 4). The use of total rewards strategy in municipal organisations as proposed by this study thus emanates partly from the views proposed in the NPM theory.

In addition, the Constitution of the Republic of South Africa, 1996 provides in section 195 (h) that 'good human resource management and career development practices, to maximise human potential, must be cultivated'. Also, section 72 makes provision that the Minister of Department of Provincial and Local Government (DPLG) may, after consultation with the South African local government bargaining council (SALGBC), issue guidelines to provide for the development of incentives frameworks for staff members of municipalities. However, such incentive and reward system should not be in conflict with any local government legislation or binding ruling given by the DPLG, South African Local Government Association (SALGA) and/or SALGBC.
Kaur (2013) points out that people need better work relationships, work life balance, job security and salary and other benefits to keep them satisfied and contented. Hence intrinsic motivation and extrinsic motivation are important for performance of municipal tasks. Creating a working environment in municipal organisations where employees do their work well, have good relations with colleagues and where they can positively influence their workplace is imperative. Hence, the notion of total rewards which offers both financial and non-financial rewards comes into the picture.

\section{Literature review}

In the last few years the concept of total rewards has received tremendous attention in the total rewards research discourse with many researchers indicating the need for its implementation in the organisations (Armstrong \& Taylor, 2014; Bussin \& Toerien, 2015; Kaplan, 2012; Makhuzeni \& Barkhuizen, 2015). The conceptual basis of total rewards stems from its holistic approach, or philosophy, which encapsulates the sum total of financial and non-financial rewards that an organisation may give to its employees (Armstrong 2006; Nazir, Shah, \& Zaman, 2012; Tsede \& Kutin, 2013).

Many authors have suggested examples of benefits that may accrue from the implementation of a total reward strategy. Heneman $(2007$, p. 3 ) suggests that total rewards, do not only encompass compensation and benefits but also 'personal and professional growth opportunities and a motivating work environment (for example, recognition, valued job design, and work/life balance)'. Terera and Ngirande (2014) found a positive relationship between rewards and employee retention and share a similar view with Heneman by suggesting that employers should try to create a total reward structure that includes both financial and non-financial rewards as a strategy to increase retention of talent. The two researchers conclude that 'rewards do not only fulfil financial and material needs, but also provide a social status and position of power within an organisation'. Kaplan (2012) on his part suggests that through total rewards design:

Human Resources (HR) serves as a change agent, helping to connect the dots to reveal a picture of workforce synergy, with everyone focused on the attainment of common business goals. (p. 18)

Total reward strategies can also afford employers an opportunity to vary rewards across generational cohorts with rewards being tailored to the needs of a specific cohort (Bussin \& Van Roy, 2014).

The role of total rewards benefits and their positive effect on employee motivation and retention as suggested in the earlier discussion has contributed to the significance and increasing attention that many organisations now put on reward restructuring processes. For instance, in one of the surveys on total rewards conducted in the autumn of 2011 by Aon Hewitt, one-half of companies that were surveyed 
indicated that they expected total rewards to help them improve their ability to engage, retain and attract talent, while a similar number saw total rewards as a key lever to help drive improved business results (Aon, 2012).

Many authors have tried to outline the principle elements that constitute total rewards. Prominent among them is Fernandes (1998), who lists, among others, the following: basic salary, variable pay, pension benefits, death insurance benefits, private medical insurance, vocational entitlement, company schemes, share securities and mortgages. However, the total reward strategy model (TRM) that seems to be popular among HR practitioners and researchers is that of WorldatWork (2012), which classifies total rewards under six categories:

- Compensation: This provides reward for services rendered. It includes both fixed pay such as salary, variable pay like commissions and premium like the skillbased pay.

- Benefits programmes: This includes health, income protection, savings and retirement and Medicare, which provide security for employees and their families.

- Work-life effectiveness: A specific set of organisational practices, policies and programmes such as job security and teleworking. These programmes provide work flexibility to ensure that the employee manages effectively his work responsibilities and is also able to attend to personal problems and family-related issues.

- Recognition: Formal and informal programmes that acknowledge or give special attention to employee performance and contribution to organisational success.

- Performance management: The alignment of organisational, team and individual efforts towards the achievement of business goals and organisational success. This can be achieved through proper planning and employee evaluation.

- Talent development: It provides the opportunity for employee to improve their skills and knowledge through created training and learning opportunities.

The WorldatWork total reward management (TRM) model has become popular as it provides the basis for HR practitioners to experience the power of leveraging multiple factors to attract, motivate and retain talent and enable highperforming companies realise that their proprietary total rewards programmes have allowed them to excel and become more competitive (WorldatWork, 2012). Furthermore, it has broadened the research discourse on the total rewards by attracting researchers and $\mathrm{HR}$ consultants to increase their investigation on the impact of total rewards on talent retention.

However, it should be noted that the WorldatWork model is one but of many others that have sprung out in the literature explaining the significance of total rewards in explaining strategic reward options. The truth of the matter is that the model in essence encapsulates both the two motivational rewards factors: extrinsic and intrinsic motivation. Many other total reward strategy (TRS) models and many researchers agree that a (TRS) should embrace these two factors. There is a consensus among researchers and HR practitioners that a TRS should be constituted of both financial and non-financial rewards. The differences in the different TRMs are the way benefits are categorised in each model. Hence, what is in the WorldatWork TRM is likely to be similar in other models except that naming or categorisation of these rewards may be different. For instance, another significant and well-recognised model by HR practitioners is that of Tower Watson (2016). Unlike the WorldatWork model, this one compresses employee rewards into three categories: (1) the career and environment rewards such as training and development, mentor programmes, career management programmes, talent mobility, discretionary technology, flexible work programmes, corporate social responsibility and well-being programmes (2) the performance-based rewards like base pay increases (merit, promotion), recognition, short-term incentives, longterm incentives, profit-sharing plans and lastly foundational rewards that encompass pay, health care, retirement, perquisites, allowances, life and disability, wellness benefits, wellness initiatives, employee assistance programme (EAP), voluntary benefits and time off. Comparatively, one would clearly see that there are great similarities between the two models.

By including both financial and non-financial rewards, the TRS can ensure that employees are motivated towards performance excellence while sending out a strong message about what is important to the business (Jean-Claude, 2007) and can also lead to more 'personal and a stronger emotional bond between employees and the company' (Aon, 2012, p. 4). Dalvi and Ebrahimi (2013) also talk of a well-designed reward system that creates a sense of belonging among employees and enhances employee growth and development, thus increasing employee self-esteem and ultimately lead to healthier organisations.

In other respects, organisations link rewards to performance objectives in order to promote justice and fairness among diverse groups of employees. If compensation is not linked to performance, it becomes difficult for employers to give recognition where it is deserved, and issues of unfairness may creep in. Similarly, rewards as noted by Molofo (2012, p. 75) are typically the outcome of performance evaluations and as such performance management system (PMS) should be used as a tool or measure to reward performance in various ways; for example, non-financial rewards such as recognition of achievement should be used in municipalities. This is also echoed by Baird, Schoch and Chen (2012) who assert that employees will feel valued if they are equitably compensated for their efforts and that without a link between performance and rewards, poor performers may not be motivated to improve

The challenge though is that in most municipal organisations, PMSs are very ineffective and there is low compliance in many municipalities. Hence, the idea of a using a PMS to 
promote the TRS is likely to lead to impediments towards its implementation. However, this is not an excuse for municipal HR managers not to apply TRSs. By not undertaking reward restructuring, municipalities fall short of enjoying the benefits that are assumed to accrue from total reward strategies. There are many benefits that municipalities could exploit by using this strategy. Research on compensation pay systems has advocated for reward approaches that include benefits such as fairness and recognition. For organisations such as municipalities, which comprise diverse groups of employees, issues of equity, justice and fairness are of paramount importance and an effective pay system should be informed, among others, by these attributes. This is to ensure that employees do not perceive the pay system as being unfair. Moreover, 'pay systems are strategically designed when rewards are linked to activities, attributes and work outcomes that support the organisation's strategic direction and foster the achievement of strategic goals' (Howard \& Dougherty, 2004, p. 41).

Municipalities should create a strong performance culture with effective rewards and sanctions (Engela \& Ajam, 2010, p. 14) and should also ensure that rewards are linked to the agreed performance goals (Bussin, 2017). For instance, municipalities like Cape Agulhas developed a Performance Management Policy Framework, which aims not only at rewarding and recognising performance but also recognise that for this to happen good performance managements systems must be in place. The PMS should be characterised by the introduction of innovations that add value to the municipality and the broader community or by performing excellently in terms of own performance. Rewards that could be applicable could include improvement performance awards, merit certificates and year-end awards (Cape Agulhas Council resolution 125/2015).

\section{Problem statement}

The role of total rewards in achieving business goals, employee productivity and employee retention cannot be underestimated. A total reward strategy has been linked to the entire employee proposition, thus making it one of the most critical factors in the attraction and retention of talent in organisations. While there are profound arguments for organisations to develop and implement total reward strategies, many organisations, including South African municipalities, are still using traditional reward systems, where compensation is dominated by base pay and benefits. The problem with traditional reward systems is that they do not communicate or support strategic business priorities and are inflexible and not reflective of business results (JeanClaude, 2007). They are based on tenure, entitlement and internal equity. Furthermore, when a total reward approach is used, it can result in 'well-structured reward systems, which can enhance satisfaction and fairness' (Howard \& Dougherty, 2004, p. 41). It is against the backdrop of these assertions that this paper wishes to investigate and explore the extent South African municipalities are implementing total rewards as a basis of their reward system and to find out which total reward practices are implemented by municipalities as part of their compensation and reward strategy.

\section{Goal of the study}

The goals of the study were to:

- investigate the extent municipalities use total rewards as part of their reward strategy

- provide suggestions or recommendations as to how municipalities would establish favourable conditions for the implementation of total reward practices for their employees.

\section{Research methodology Research design}

The research design for the study was internet-based, using a questionnaire as the main data collecting tool. The main contact and response mode was e-mail. A non-list-based random sampling technique was used to draw up a sample of 58 human resources managers from selected municipalities. One hundred and fifty-eight municipalities were randomly selected from all the nine provinces to request for their contacts and willingness to participate in the survey. Of the contacted municipalities, only 58 declared their intention to participate. Of the 58 municipalities that participated in the online survey, only 23 returned their questionnaire, thus giving a response rate of $40 \%$.

This sampling technique was chosen because it was difficult to have an existing list of e-mail addresses of managers to serve as the sample frame for the selected municipalities. The e-mail list that was assembled by the researchers was in addition used as the sample for the study. This is in agreement with Fricker's suggestion (2008) that surveys using non-listbased sampling allows for the selection of a probabilitybased sample without the need to actually enumerate a sampling frame.

The study was based on six itemised variables that were presented in the form of a questionnaire. One of the six items (extent to which municipalities have adopted total reward strategies) was treated as a single variable. It explored the extent to which municipalities use total reward strategies as part of their rewards practices. Each of the remaining five items was identified as a reward practice that could form part of an organisational total reward strategy. Therefore, respondents were asked to indicate whether each of those practices form part of their strategy. The questionnaire was first pretested to some of the researchers' colleagues and a few of respondents to the survey. An informed consent form was sent to participants to explain to them the objectives, nature and type of research and to ensure that the main ethical issues related to this survey were clearly explained to them before they could decide to participate. Permission to conduct survey was granted by either the municipal managers or HR managers depending on the protocols followed by each municipality. The overall response to the 
study was $40 \%$, with the most positive response coming from the metropolitan at $80 \%$, followed by district municipalities at $58 \%$, and last, the local municipalities at $29 \%$.

\section{Data analysis}

Data collected were tabulated and analysed using the descriptive statistics generated by the Statistical Package for Social Sciences. A reliability analysis was also conducted on five of the six items of this study with a view to understanding the level or degree of internal consistency and the reliability of the variables in the group scale. Furthermore, this analysis established the degree of internal relatedness among items in the scale. Findings indicated a high degree of internal consistency among the items in the scale with a Cronbach's alpha of 0.865 .

\section{Results}

This variable was intended to assess the extent to which municipalities are implementing total rewards as part of their compensation system. A significant number of the respondents $(76.2 \%)$ indicated that their organisations do not use this strategy, while only $23.2 \%$ believed that their organisations did so (See Table 1). The results show that to a large extent municipal organisations are not implementing the total reward strategy.

Table 2 presents the results from five selected practices that the study used to explore and evaluate further the extent to which municipal organisations have implemented total rewards practices as part of their rewards strategy. Table 2 shows the extent to which municipalities use selected practices as part of total reward strategy.

On whether components of their organisation's rewards strategy included monetary compensation, fringe benefits and development opportunities, results were inconclusive because of the fact that those respondents who believed that their strategies did so (35.7\%) were exactly the same number as those that believed their organisational reward strategy did not. However, there was a slightly reasonable percentage of those who were probably unsure or undecided (28.6\%), which could probably indicate uncertainty in relation to the implementation of total reward strategies in municipalities.

When respondents were asked to indicate whether their rewards strategy provided meaningful pay differentiation to high performers or high potentials through both base and variable pay, more than half $(56.4 \%)$ were of the opinion that their reward strategies did not. Fewer than $10.0 \%$, agreed and over a third $(35.7 \%)$ were undecided or unsure.

On whether their reward strategies ensured that pay and recognition were proportional to employees' performance, a significant number of respondents $(71.5 \%)$ disagreed with this statement. This is a clear indication that municipal reward strategies of the participating municipalities do not match rewards and compensation with performance and recognition of employees.

Respondents were further asked to indicate whether they agree with the statement that their organisational pay system is designed to promote justice and fairness among the diverse groups of employees. Results show that more than two-thirds $(67.2 \%)$ of the respondents do not agree with this statement. Just over a third (35.7\%) agreed and 7.1\% were undecided or unsure. These results clearly show that reward strategies of the responding municipalities are not perceived to promote justice and fairness through prioritising issues such as gender, age, ethnicity and so on in their remuneration strategies.

On whether reward strategies were compliant to the legal prescripts and to the corporate governance of South African

TABLE 1: Extent to which municipalities have adopted total reward strategies.

\begin{tabular}{llccc}
\hline $\begin{array}{l}\text { The extent to which } \\
\text { municipalities use total } \\
\text { reward strategies }\end{array}$ & Categorical responses & Frequency & Cumulative \% & Valid \% \\
\hline Valid & Yes & 5 & 21.7 & 23.8 \\
& No & 16 & 69.6 & 76.2 \\
& Total & 21 & 91.3 & 100.0 \\
Missing & System & 2 & 8.7 & - \\
\hline Total & & $\mathbf{2 3}$ & $\mathbf{2 3 . 0}$ & - \\
\hline
\end{tabular}

TABLE 2: Extent to which municipalities use selected practices as part of total reward strategy.

\begin{tabular}{|c|c|c|c|c|c|}
\hline Variable & $\begin{array}{l}\text { Strongly disagree } \\
(\%)\end{array}$ & $\begin{array}{l}\text { Disagree } \\
(\%)\end{array}$ & $\begin{array}{l}\text { Neither agree nor } \\
\text { disagree (\%) }\end{array}$ & $\begin{array}{c}\text { Agree } \\
(\%)\end{array}$ & $\begin{array}{c}\text { Strongly agree } \\
(\%)\end{array}$ \\
\hline $\begin{array}{l}\text { Components of my organisation's total rewards strategy } \\
\text { include monetary compensation and benefits and } \\
\text { development opportunities }\end{array}$ & 14.3 & 21.4 & 28.6 & 35.7 & - \\
\hline $\begin{array}{l}\text { Our reward strategy provides meaningful pay } \\
\text { differentiation to high performers or high potentials } \\
\text { through both base and variable pay }\end{array}$ & 28.8 & 28.6 & 35.7 & 7.1 & - \\
\hline $\begin{array}{l}\text { Ensure that pay and recognition are proportional to } \\
\text { employees' performance }\end{array}$ & 28.6 & 42.9 & 14.3 & 14.3 & - \\
\hline $\begin{array}{l}\text { The pay system is designed to promote justice and fairness } \\
\text { among the diverse groups of employees }\end{array}$ & 14.3 & 42.9 & 7.1 & 28.6 & 7.1 \\
\hline $\begin{array}{l}\text { The reward strategy is compliant to the legal prescripts } \\
\text { and to corporate the governance of South African } \\
\text { municipalities }\end{array}$ & 18.2 & - & 27.3 & 36.4 & 18.2 \\
\hline
\end{tabular}


municipalities, more than half $(54.6 \%)$ of the respondents agreed that their reward strategies were compliant. Only $18.2 \%$ disagreed, while $27.3 \%$ were undecided. It would seem that this level of compliance is probably a result of other stakeholders' intervention, such as the government and municipal councils. However, the fact that just over $50.0 \%$ agreed is a testimony that even compliance still falls far short of the ideal position that is required from municipalities to comply with the legal prescripts and corporate government

\section{Discussion}

Findings clearly indicate that to a large extent municipal reward system still relies on traditional methods of compensation. This is underlined by the key findings which revealed that more than two-thirds of the participating municipalities have not developed total reward strategies. These findings are replicated in other studies and surveys. For instance, the SARA SURVEY, a South African study by Ernst \& Young (Sika, 2014) indicates that only $45 \%$ of the investigated companies successfully implement total rewards and just $21 \%$ plan to implement total rewards. The Thomson Survey (2011) as indicated in Sika (2011) also indicates that only $38 \%$ of those companies that participated in their survey have a written reward strategy.

According to Aon (2012, p. 10), organisations are putting great interest in finding ways to unlock the potential that total rewards offers as a management tool, but 'are struggling to find the right combination'. Furthermore, a total rewards strategy as Aon (2012, p. 22) continues to suggest that 'the map that guides the management of rewards programmes, yet it seems as though most firms have chosen a destination but are navigating without a map'. It is clear that in most organisations there is will to implement TRS but seemingly there is a lot more for most organisations, including South African municipalities to learn before they can be able to implement successful total reward strategies. What is clear today is that many of these organisations are now spending huge sums of money and putting great effort into the redesigning of their reward strategies (Aon, 2012; Howard \& Dougherty, 2004; Jean-Claude, 2007).

Findings from the study to a large extent indicate that compensation practices in municipalities include both monetary compensation and non-monetary benefits. However, they fall short of including development opportunities for employees. In addition, a significant number of the responding organisations in the study reveal that municipal pay systems do not attract high performers (Howard \& Dougherty, 2004). This limitation as seen in current literature is likely to undermine retention efforts in organisations (Jean-Claude, 2007; Howard \& Dougherty, 2004; Kaplan, 2012). High-performing organisations, as McCormick (2015, p. 5) asserts, 'Differentiate rewards to create an external competitive advantage and target critical internal populations like high-potential employees, top performers, and women to develop, engage, and retain employees'. In addition, they also actively and regularly communicate their total rewards strategy to employees.
Research on compensation pay systems has advocated for reward approaches that promote intangible rewards such as fairness and recognition. Organisations link rewards to performance objectives and should promote justice and fairness among the diverse groups of employees. The key finding for this study reveal municipal pay systems that are not designed to promote justice and fairness.

These findings tend to concur with the findings revealed in the SALGA study (2010) where municipal managers and managers directly accountable to the municipal managers, within the same classification of municipalities, were found to be paid very different salaries. The COGTA Report also shows gender salary gaps and gaps among employees belonging to different ethnic backgrounds (COGTA, 2009). In addition, there are wide variations in the salary scales of employees in similar size municipalities, as noted by the National Treasury Budget Review (COGTA, 2009). This kind of perceived unfairness in pay systems may lead to stress, which may subsequently, contribute to costs of turnover, accidents and illness (Howard \& Dougherty, 2011).

In a study that was conducted in 2004 by PricewaterhouseCoopers (McCormick, 2015), pay satisfaction and perceived pay equity were identified as key drivers of retention. The perceived inequity in the municipal pay system is likely therefore to increase turnover problems and has also the capacity to worsen the scarce skills gap in these organisations. It may be argued further that perceived unfairness arouses 'dysfunctional emotions, including anger, depression and anxiety that can contribute downstream to undesirable responses, including theft, absenteeism and alcohol use' (Howard \& Dougherty, 2004, p. 42). These problems mentioned may affect the level of organisational commitment (OC) of employees of municipalities (Dzansi \& Dzansi, 2010). It is therefore imperative that municipalities being public entities should be encouraged to develop pay systems that promote justice and fairness to all employees. However, the problem, as Brewer and Kellough (2016) assert, will be how managers and supervisors are able to find the right balance between the need for the flexibility necessary to guide their organisations effectively and the simultaneous need to ensure fairness and equity in the way employees are treated.

It is clear from the findings that municipalities' pay systems are not aligned to employees' performance and employees are rarely recognised for their performance. More than twothirds of the respondents in the study perceive this to be true. According to Howard \& Dougherty (2004, p. 43), reward strategies can be tied to 'individual output to encourage individual work effort; group output to encourage teamwork and collective effort and human capital to encourage development of skills and flexibility...' The feeling of individual's performance not being recognised can have a great impact on one's motivation and commitment to the organisation. Key findings on compliance to the legal prescripts and corporate governance show average levels of 
compliance. However, these findings may be viewed sceptically. Compliance to legal prescripts and good corporate governance would be promoted by fair and equitable elements in the pay system, which according to key findings for this study, are lacking.

\section{Conclusion}

The researchers do not doubt the insurmountable challenges that face municipal HR managers in their quest to develop and implement total rewards strategies. The greatest challenge to municipal organisations is the severe shortage of skills as well as human resources (Financial and Fiscal Commission Policy Brief, 2012; Koma, 2010). The situation is even worsened by a high turnover rate and budget limitations. Municipalities also suffer from political and union interference, which in some cases can influence or undermine strategic HR decisions later alone inculcating bureaucratic tendencies of municipal employees to execute established policies by politicians. Added to this also is the issue of poor PMSs, which are only aimed at mostly section 57 managers. Section 57 is a term commonly used to refer to managers employed in accordance with the requirements of the Republic of South Africa (RSA, 2000) section 57 of the Local Government: Municipal Systems Act, 2000 (Act No. 32 of 2000). They consist of the municipal manager or the accounting officer, the chief financial officer, all senior managers and any other senior officials designated by the accounting officer.

The fact that most municipalities have not cascaded their PMS to other employees at the lower levels is a problem in that a large part of the employees at the lower levels do not actively go through efficient performance evaluation and monitoring processes, thus rendering them unsuitable to performance related benefits and promotions.

However, researchers have pointed out that the contribution total rewards benefits can make on the motivation and retention of employees in organisations is quite immense such that it would be in the interest of municipalities to try and implement reforms dedicated at the restructuring of their rewards systems. In an environment where employees are increasingly becoming knowledgeable of competitors pay packages, where global competition continues to tighten and where many employees are becoming more and more attracted to diversified pay packages (Bussin \& van Roy, 2014), the survival of organisations will depend on how best and most effective such organisations can design and implement rewards systems that can develop, engage, motivate and retain employees. This paper tries to offer or suggest ways in which municipalities can create favourable conditions to respond to the issue of how a total reward strategy could be implemented in the municipal sector.

\section{Recommendations}

The current compensation and reward practices in municipalities in the study expose weaknesses in relation to the development and implementation of total reward strategies. The study findings are clear that municipalities are still using traditional remuneration policies. This to a great extent is a result of the many challenges identified in the previous section that municipal organisations face. In light of the fact that these challenges are not likely to go away soon, the paper therefore proposes the following recommendations to assist municipal HR managers in creating favourable conditions for the implementation of a total reward strategy.

Firstly, for municipalities to become employers of choice that can attract the required talent capable of ensuring effective service delivery, they will need to develop competitive reward strategies that can command high employee satisfaction, loyalty and commitment to the organisation. Such strategies should be aligned to organisational goals; employee needs; recognition; and employee performance, evaluation, training and development. How to navigate through this undertaking, municipal organisations need to devote large amounts of resources to train and develop managers in the design and implementation of the TRSs. In dealing with the question of budget limitations and other external challenges such as the bureaucratic tendencies, political and union interference, managers will need to enter into corroborative efforts and partnerships with other stakeholders, such government (DPLG), unions, SALGBC, SALGA and where possible private organisations to seek a common understanding on how compensation and rewards reform decisions could be initiated and implemented.

Secondly, as part of internal management and control, municipalities need to consider seriously the implementation of performance evaluation and monitoring of all their employees because as already indicated in the previous sections of this paper, employee rewards need to be linked to performance in order to compensate for the top performers and also reward those that make strides to improve their performance. The cascading of PMs in municipalities can be achieved through effective communication and negotiations with all stakeholders, especially trade unions and employees in their respective work units. However, in the meantime, municipal managers can also exploit the little available avenues created by legislations such as the South African Constitution, the Public Finance Management Act and the Local Government and the Municipal Systems Act, 2000 (Act No. 32 of 2000), etc. to find out as to what extent such legislations can permit them to engage in some form of performance evaluation, monitoring and accountability at all levels.

Also, municipalities should strive to improve on their compliance to the implementation of PMSs, accountability processes and also work hard to produce clean audits because these audits contribute to the level municipalities can be afforded to work independently and the level they can be financed. Clean audits can also improve the municipal sector's image to attract skilled employees from outside. 
Last but not least, leveraging HR issues like employee rewards to organisational top priorities will ensure that the process is supported from the top and therefore seen as a strategic issue. This will assist HR managers to get the 'buy in' they need while selling the idea of total reward strategies to top officials, unions and the government and other strategic partners.

\section{Acknowledgements}

The authors wish to acknowledge the great contribution of Prof. Collins Miruka, formally of the Mafikeng's Graduate School of Business, North-West University and the University of North-West. Prof. Miruka guided and supervised the PhD dissertation (of P.W.B.) on which some of the findings of this research paper are based. The researchers want to express their appreciation for any other assistance, be it in kind or otherwise that was received from North-West University and Walter Sisulu University.

\section{Competing interests}

The authors declare that they have no financial or personal relationships that may have inappropriately influenced them in writing this article.

\section{Authors' contributions}

P.W.B. (principal investigator) made the conceptual contribution and theoretical framework, did literature review, did the reference section, collected data, did the analysis of data and discussion of results, did the conclusion and recommendations and compiled the first draft. N.M. compiled the abstract, did the research design, collected data, contributed to the discussion of results and recommendations, compiled the second draft, restructured and compiled the final draft and did the referencing section and the proof-reading.

\section{Funding information}

Walter Sisulu University - Division of Academic Affairs \& Research (The Research Directorate) funded the article processing page fees.

\section{References}

Adams, J. S. (1965). Iniquity in social exchange. Advances in Experimental Psychology 4, 267-299. https://doi.org/10.1016/S0065-2601(08)60108-2

Alderfer, C. P. (1989). Theories reflecting my personal experience and life development. Journal of Applied Behavioral Science, 25(4), 351-365. https://doi.org/ $10.1177 / 002188638902500404$

Aon, H. (2012). Transforming potential into value, Total rewards survey. Retrieved from http://www.aonhewitt.com

Armstrong, M. (2006). A Handbook of employee reward management and practice (2nd ed.). London: Kogan Page.

Armstrong, M., Brown, D., \& Reilly, P. (2009). Increasing the effectiveness of reward management. Brighton: Institute for Employment Studies.

Armstrong, M., \& Taylor, T. (2014). Armstrong's handbook of human resource management practice. New York: Kogan Page Publishers.

Baird, K., Schoch, H., \& Chen, J. (2012). Performance management system effectiveness in Australian local government, Pacific Accounting Review, 24(2), 161-185. https://doi.org/10.1108/01140581211258461
Brewer, G. A., \& Kellough, J. E. (2010). Administrative values and personnel management: Reflection on civil service reform. Public Personnel Management 45(2), 171-189. https://doi.org/10.1177/0091026016644626

Bussin, M. (2017). Performance management reboot. Randburg: KR Publishing.

Bussin, M., \& Toerien, W. C. (2015). Influence of reward preferences in attracting, retaining, and motivating knowledge workers in South African information technology companies. Acta Commercii, 15(1), 1-13. https://doi.org/10.4102/ ac.v15i1.290

Bussin, M., \& van Roy, D. J. (2014). Total reward strategy for a multi-generational workforce in a financial institution. South African Journal of Human Resource Management, 20(1), 1-11. https://doi.org/10.4102/sajhrm.v12i1.606

Cameron, R. (2009). New public management reforms in the South African public service: 1999-2009. Journal of Public Administration, 44(4/1), 910-942.

Dalvi, M., \& Ebrahimi, H. (2013). Investigating the effects of reward on the cooperation in the sale and Marketing Department from Managers' Perspective (Isfahan Food Industries Case Study). International Journal of Academic Research in Business and Social sciences, 3(1), 144-153.

Department of Cooperative Governance and Traditional Affairs (COGTA). (2009). The state of the local government: Overview report (RSA). Retrieved from http://www. gov.za

Dzansi, D. Y., \& Dzansi, L. W. (2010). Understanding the impact of human resource management practices on municipal service delivery in South Africa: An management practices on municipal service delivery in South Africa: An organisation 1005.

Engela, R., \& Ajam, T. (2010). Implementing a government- wide monitoring and evaluation system in South Africa. ECD Working Paper Series, No. 21, Washington, DC: The World Bank.

Fernandes, F. N. (1998). Total reward-An actuarial perspective. Actuarial Research Paper, No.116. Faculty of Actuarial Science and Insurance, University of London. Retrieved from http://openaccess.city.ac.uk/2245

Financial and Fiscal Commission Policy Brief. (2012). Lack of capacity is crippling delivery of services in municipalities. Retrieved from http://www.ffc.co.za/

Fricker, R. D. Jr. (Ed.). (2008). The Sage handbook of online method. London: Sage.

Heneman, R. L. (2007). Implementing total rewards strategies, A guide to successfully planning and implementing a total reward system. SHRM Foundation. Retrieved from http://www.shrm.org/foundation

Howard, L. W., \& Dougherty, T. W. (2004). Alternative reward strategies and employee reactions: Compensation and benefits review. Sage. Retrieved from http:// journals.sagepub.com/doi/abs/10.1177/0886368703261273

Jean-Claude, B. (2007). Defining best practice incentive and reward strategies. Insight Newsletter no 5, Achievement Awards Group. Retrieved from http://www. awards.co.za/images/extra/insight_may09_iss5_3.pdf

Jiang, Z. (2009). Total reward strategy: A human resources management strategy going with the trend of the time. International Journal of Business Management, $4(11), 177-183$. https://doi.org/10.5539/ijbm.v4n11p177

Kaplan, S. L. (2012). Business strategy, people strategy and total rewards. Benefits \& Compensation, 44(9), 12-19.

Kaur, J. (2013). The role of psychological well-being and its impact on the motivational level of the employees in it sector. Kaur International Journal of Advanced Research in Management and Social Sciences, 2(6), 43-51.

Koma, S. B. (2010). The state of local government in South Africa: Issues, trends and options. Journal of Public Administration, 45(1.1), 111-120.

Makhuzeni, B., \& Barkhuizen, E. N. (2015). The effect of a total rewards strategy on school teachers' retention. South African Journal of Human Resource Management, 13(1), 1-10. https://doi.org/10.4102/sajhrm.v13i1.699

Maslow, A. H. (1943). A theory of human motivation. Psychological Review, 50(4), 310-396. https://doi.org/10.1037/h0054346

McCormick, H. (2015). Rethinking total rewards. Kenan-Flagler Business School, UNC Executive Development. Retrieved from https://www.kenan-flagler.unc.edu/

Molofo, M. (2012). Strengthening PMS implementation in South African municipalities. Africa's Public Service Delivery and Performance Review, 1(1), 67-80.

Nazir, T., Shah, S. F. H., \& Zaman, K. (2012). Literature review on total rewards: An international perspective. African Journal of Business Management, 6, 3046-3058.

Republic of South Africa (RSA). (1996). The constitution of the Republic of South Africa Act, 1996 (Act 106 of 1996). Pretoria: Government Printer.

Republic of South Africa (RSA). (2000). The Local Government Municipal Systems Act 2000 (Act 32 of 2000). Pretoria: Government Printer.

Sika, A. (2011). The total rewards concept: Getting from theory tom practice. paper presented at SARA Conference October 2011, Ernest and Young, October 2011. Retrieved from http://www.sara.co.za/sara/file\%20storage/Documents/Arthur $\%$ 20Sika.pdf

Skinner, E. A., \& Belmont, M. J. (1993). Motivation in the classroom: Reciprocal effects of teacher behaviour and student engagement across the school year. Journa of Educational Psychology, 85(4), 571-581. https://doi.org/10.1037/0022-0663. of Educa

South African Local Government Association (SALGA) (2010). State of South African local government: A focus on labour relations, capacity building and human resource management. Paper presented for discussion at HR policy conference, Limpopo. Retrieved from https://www.doi.org.10.5901/mjss. 2014.v5n1p481 
Terera, S. R., \& Ngirande, H. (2014). The impact of rewards on job satisfaction and employee retention. Mediterranean Journal of Social Sciences, 5(1), 481-487. https://doi.org/10.5901/mjss.2014.v5n1p481

Tower, W. (2012). Total rewards strategies for the 21st century. The $2012-2013$ Gebal Talent Management and Rewards Study. Retrieved from http://www. towerwatson.com/en/.../Total-Rewards
Tsede, O. A., \& Kutin, E. (2013). Total reward concept: A key motivational tool for corporate Ghana. Business and Economic Research, 3(2), 173-182. https://doi. org/10.5296/ber.v3i2.4291

WorldatWork. (2012). The talent management and reward imperative for 2012 Leading through uncertain times. WorldatWork and Tower Watson. Retrieved from https://www.worldatwork.org 